\title{
Ownership and Use of Laptops by Communication and Information Sciences Undergraduates at the University of Ilorin Nigeria
}

\author{
Adeyinka Tella \\ Department Library and Information Science, Faculty of \\ Communication Sciences, University of Ilorin, Nigeria
}

tella.a@unilorin.edu.ng, tellayinkaedu@yahoo.com

\author{
G. A. Kosoko-Oyedeko \\ Micheal Otedola College of Primary Education (MOCPED), \\ School of Arts, ChristiaReligious Studies Department, \\ Inaforija, Epe, Lagos State, Nigeria
}

gaa oyedeko@yahoo.com

\begin{abstract}
Beginning from 2010/2011 academic session, the faculty of communication and information sciences, university of Ilorin, Nigeria requires that each student of the faculty should as a matter of compulsion have a laptop (notebook computer) sufficiently equipped to be used to support essential research, classroom, and communications tasks. Upon arrival in the faculty during the academic session, students were thoroughly screened and those that were not with their laptops were not allowed to register until they procure one. The study therefore examined ownership and use of laptop among the information and communication sciences students at the University of Ilorin, Nigeria. The study drawn on 295 students randomly selected from five departments that made up the faculty. A survey research design was adopted using a questionnaire as instrument for data collection. The results demonstrate that aside of being mandatory, students own and use laptop because they want to be like others and to show that they are Communication and Information Sciences students. It is not difficult owning personal laptop because it was bought or purchased by the respondents' parents. To overcome problem of laptop acquisition, hire purchase and installmental payment, loans, price subsidy, and inclusion of payment for laptop in the respondents' school fees were identified. The benefits of laptop revealed include: use for academic purpose including assignments and research, provide access to online discussion forum and make aca-

Material published as part of this publication, either on-line or in print, is copyrighted by the Informing Science Institute. Permission to make digital or paper copy of part or all of these works for personal or classroom use is granted without fee provided that the copies are not made or distributed for profit or commercial advantage AND that copies 1) bear this notice in full and 2) give the full citation on the first page. It is permissible to abstract these works so long as credit is given. To copy in all other cases or to republish or to post on a server or to redistribute to lists requires specific permission and payment of a fee. Contact Publisher@InformingScience.org to request redistribution permission.

demic work easier and faster; while the challenges of using laptop revealed by the study include lack of access to the internet connectivity in the faculty, intermittent power supply, theft and virus threat. In the light of these findings, the major stakeholders in this faculty i.e. the ministry of information and communication in Nigeria is hereby call upon to give at least a laptop each to every students of the faculty free of charge. It is
\end{abstract}


assumed that this will lessen the burden of most parents in procuring the system for their wards, and the ownership of laptops by the each student will assist them in deepened their knowledge in their various courses and disciplines.

Keywords: ICT, Laptop, Communication and Information Sciences, Undergraduate student, University of Ilorin, Nigeria.

\section{Introduction}

The development of Information and Communication Technology (ICT) has undoubtedly created many opportunities for development in all governmental sectors including the educational sector. Globally, things are now going in the direction of ICT. In order words, any country, organisation or industries that is not going in this direction is assumed to be dwelling in the past. The Information and Communication Technology has been rapidly expanding all over the world with increased ICT usage in all forms of day-to-day activities across all the sectors. This unprecedented growth in the ICT industry has resulted in a widening gap between the supply of IT professionals and the available positions in the industry leading to a significant shortage of manpower. As a result of the ICT revolutions, universities the world over are now considering establishing department and faculty to cater for the training and production of young graduates in Information Communication Technology or its related allied disciplines. These graduates are expected to serve the growing information organisations. To address this at the national level, the University of Ilorin, Nigeria established the Faculty of Communication and Information Sciences in 2008. Interestingly, this happened to be the first of this kind in Nigeria.

Beginning from 2010/2011 academic session, the faculty requires that each student of the faculty should as a matter of compulsion have a laptop (notebook computer) sufficiently equipped to be used to support essential research, classroom, and communications tasks. Upon arrival in the faculty during the academic session, students were thoroughly screened and those that were not with their laptops were not allowed to register until they procure one. The faculty of communication and information sciences, University of Ilorin Nigeria is convinced that requiring all students to own laptop will increase their productivity and efficiency, improve institutional communications, and prepare students to effectively use this essential academic and business tool. Not only this, it is assumed that ownership of laptop by the individual students of this faculty will make them unique as students of information faculty. And similarly, the key to successfully adopting laptop technology was to ensure that students remained academically engaged with the device on a regular basis so that they became accustomed to its use borrowed from the idea by (Mang and Wardley, 2012).

Over the past decade, rapid technological advances have sparked interest in utilizing laptops as an instructional tool to improve student learning. The regulation on compulsory ownership of laptop is not new. Newby (2000) reported a large, highly ranked public university implemented a requirement for all incoming undergraduates to own a laptop computer starting in fall, 2000. It is now widely accepted that effective use of technologies such as software, spreadsheets, graphics and CAS calculators, and data logging equipment offers students new opportunities for fast, accurate computation, collection and analysis of real or simulated data, and investigation of links between numerical, symbolic, and graphical representations of concepts. It has also been established that use of technology usually enhances information creation, retrieval, processing, and dissemination. Considering the ongoing global economic recession and its impacts on individual family, this study wish to examine how easier the students find owing and procuring a laptop, investigate how useful the laptop is to their programme of study and the challenges of owning and using the laptop in the faculty of CIS. Evidently, study of this kind has not been conducted since the inception of the faculty in 2008 and since the laptop ownership mandate in 2010/2011 academic session. Not this alone, research examining ownership of information communication technology 
tools is currently lacking in Nigeria. Against these backdrops, this study will constitute one of the pioneer studies in this area thereby contribute to the limited available literature.

\section{Literature Review}

\section{Brief History of the University}

The University of Ilorin is located in the ancient city of Ilorin, about 500 kilometres from Abuja, the Federal capital. Ilorin, the Capital of Kwara State, is strategically located at the geographical and cultural confluence of the North and South. University of Ilorin was one of the seven institutions of higher learning established by a decree of the Federal Military Government in August, 1975. This step, taken to implement one of the educational directives of the country's Third National Development Plan, was aimed at providing more opportunities for Nigerians aspiring to acquire university education and to generate high level man-power, so vital for the rapidly expanding economy.

The then University College of Ilorin was initially affiliated to the University of Ibadan. The University College had three foundation Faculties namely: Arts, Science and Education. The Institution began to develop its programmes in a way that not less than $60 \%$ of its effort was directed towards science-oriented programmes.

In October 1977, the Institution attained full autonomous status and has since then developed by leaps and bounds. The student population of 200 in 1976 has increased to 28,554 by the $2009 / 2010$ session, while the total staff strength of the University stood at approximately 3,040 as at March 1, 2010. Up till January 2011, the University carried out its academic programmes, involving the Faculties of Agriculture, Arts, Basic Medical Sciences, Business and Social Sciences, Communication and Information Sciences, Clinical Sciences, Education, Engineering \& Technology, Law, Pharmaceutical Sciences and Veterinary Medicine.

The faculties began to increase in number from three faculties in 1976, today there are twelve faculties: Arts (1976), Science (1976), Education (1976), Engineering and Technology (1978), Business and Social Sciences (1981), Agriculture (1982), Law (1993, after an initial start-up in 1983), Basic Medical Sciences (2004), Clinical Sciences (2004),Communication and Information Sciences(2008), Veterinary Medicine (2011) and Pharmaceutical Sciences (2011).

Altogether, there are over 70 academic departments in the existing twelve faculties. Undergraduate degree programmes run for 3, 4, 5, or 6 years, depending on entry qualifications and discipline. The University started with the traditional British "Three Term System" but later changed into a modified form of the American "Two Semester System" called Harmattan and Rain semesters with effect from 1979/80 session.

Each semester comprises one half of an academic year as determined by Senate. Also instruction in the various Faculties with the exception of the Health Sciences is by the course system. These courses are quantified into credits. The University has teaching support units which include the Computer Centre, Central Workshop and Stores, Biological Garden, Community Based Experience and Services (COBES), Medical Educational Resources Unit, General Studies (Use of English/National Awareness) Division, and Teaching and Research Farm. There is also a Computer-Based Testing (CBT) used to examine any class that is larger than 500 students to ensure thoroughness, accuracy and fairness. There are also the Public Units which are the University School, the University Secondary School, Institute of Education and Educational Technology Centre. Although an academic unit, the Library is actively involved in rendering service to the University and the public. In addition, there is a Sugar Research Institute which is mainly a research unit served by academic mainly from Science and Agriculture Faculties. 


\section{The Faculty of Communication and Information Sciences}

The Faculty of Communication and Information Sciences (CIS) was formally established via the decision of the Senate at its 193rd (Special) meeting held on 20th June, 2008. Part of that Senate decision was the movement to CIS of the Department of Computer Science from the Faculty of Science; and the movement to CIS of the Department of Mass Communication from the Faculty of Business and Social Sciences. In addition to the decision to move these two departments, was also the decision to formally commence activities in the Departments of Library and Information Science, Information and Communication Science, and Telecommunication Science.

The Faculty of Communication and Information Sciences is the University's flagship faculty designed to take full advantage of multidisciplinary interactions of the science and technologies of computing, information and communication. Its undergraduate curriculum is designed to reflect this and underlies the Faculty's postgraduate programmes. The faculty consists of five departments namely: Computer Science; Information and Communication Science; Library and Information Science; Mass Communication and Telecommunication Science.

\section{Theoretical Foundation}

Rapid technological advances in the last decade have sparked educational practitioners' interest in utilizing laptops as an instructional tool to improve student learning. There is substantial evidence that using technology as an instructional tool enhances student learning and educational outcomes. Past research suggests that compared to their non laptop counterparts, students in classrooms that provide all students with their own laptops spend more time involved in collaborative work, participate in more project-based instruction, produce writing of higher quality and greater length, gain increased access to information, improve research analysis skills, and spend more time doing homework on computers. Research has also shown that these students direct their own learning, report a greater reliance on active learning strategies, readily engage in problem solving and critical thinking, and consistently show deeper and more flexible uses of technology than students without individual laptops.

It is important to consider the benefits that laptop computers provide in the learning environment, especially in comparison to desktop computers. Laptops' portability helps students use technology because it is lightweight and can operate on batteries. Laptops can be passed among students, moved around the classroom, carried in school and on field trips, and taken home and can fit in backpacks and can be carried anywhere.

Laptops facilitate data sharing and processing by students. Students can share a laptop and take turns to view, input, and analyze data. Individuals or groups can transfer information using file sharing programs and/or wireless connectivity. Students at different locations can interact through email or videoconferencing, using wireless connectivity among computers, or a modem. Laptops provide ready access to Internet resources, even in the field, using wireless remote access. The ability to process and graph data immediately allows students to check estimates and make decisions about the next step of an activity in the field or laboratory. The flexibility of laptops lets students become more interested in learning, this is the key to effective education and positive self-esteem is.

Laptops have similar advantages for teachers. In the classroom, teachers can connect laptops to monitors or overhead projectors to give multimedia presentations, clarify assignments, and review procedures. Teachers can use laptops to record and organize notes on individual student progress; and they can also use the computers in conjunction with digital cameras to record events for later student assessment. Similarly, laptops facilitate communication between students and teachers: using a laptop at home or in the field, students can submit assignments or questions via email or wireless connectivity. 
Furthermore, Laptops are used in a wide range of ways but overall teachers use the laptops mainly in the teaching-learning process, preparing and planning of lessons, and in finding resources. Continuous use of laptops do substantially increased competency in handling the ICT equipments. In the context of teaching-learning, it is observed that when laptop was being used, it increased student attainment and they were more engaged in learning. These observations are similar with the evaluation of Fullerton School District Laptop programme by Warschauer and Grimes (2005) and Maine's One-to-One laptop programme (Silvernail \& Lane, 2004). They found that the use of this mobile technology during the teaching-learning process raises students' interests and that they are more actively involved in the learning process. On preparation and planning of lesson, the teachers had extensively expressed how the laptop had significantly improved their time management and quality of work. Previous studies have confirmed that teachers enjoyed preparing lesson plans using laptop because it saved time (Cunningham et. al, 2004) and helped produce a higher quality of work (Silvernail \& Lane, 2004). In terms of the use of resources, (Khambari et al. (2009) emphasised that laptop ownership gives users access to a greater range of resources primarily from the Internet. The ability to download resources and games was positively endorsed by these teachers who valued the greater choice and access to a range of resources that personal access to a laptop had afforded them. These findings are similar with a research by Cunningham et. al (2004) who found that personal access to laptops had allowed teachers greater freedom in accessing the Internet to search for resources.

\section{Related Studies}

Khambari et al. (2009) explored the experiences of owning and using laptops among three secondary school teachers in Malaysia. They were granted personal laptops by the Ministry of Education through the Teaching and Learning of Science and Mathematics in English, or known as Pengajaran dan Pembelajaran Sains dan Matematik dalam Bahasa Inggeris (PPSMI) programme. PPSMI was aimed at enhancing the teaching of these subjects in English with the aid of technology. The research adopted a case study qualitative approach using semi-structured interviews. Three in-depth interviews were audio recorded in the teachers' schools, transcribed and analysed. Several themes related to the benefits and challenges of owning and using laptops emerged from these interviews. This paper is relevant to this current study as it's also seeks to discuss themes such as benefits, challenges of owning laptops in detail.

The study by Gulec and Demitras (2005) examined the impact of participation in a laptop program on student achievement. A total of 259 middle school students were followed via cohorts. The data collection measures included students' overall cumulative grade point averages (GPAs), end-of-course grades, writing test scores, and state-mandated norm- and criterion-referenced standardized test scores. The baseline data for all measures showed that there was no statistically significant difference in English language arts, mathematics, writing, and overall grade point average achievement between laptop and non-laptop students prior to enrolment in the program. However, laptop students showed significantly higher achievement in nearly all measures after one year in the program. Cross-sectional analyses in Year 2 and Year 3 concurred with the results from the Year 1. Longitudinal analysis also proved to be an independent verification of the substantial impact of laptop use on student learning outcomes.

Kitchens (n.d.) reported a four-week period of the seventh-grade math students who used laptop computers to complete a unit on data analysis. The students searched for and gathered data via the Internet and e-mail and used online programs and spreadsheet software to create appropriate charts and graphs to display the data. The study revealed that the students were more engaged during this unit of study than in previous units taught with more traditional approaches to teaching and learning. Despite no evidence of academic improvement, the students produced more 
high quality work with less help from the teacher. An improvement was also noted in the students' confidence in their data analysis skills between the start of the unit and its conclusion.

Goos and Benison (2008) reported a research project that sought to develop a more sophisticated theoretical understanding of how and under what conditions teachers learn to effectively integrate technology into their practice. The aim of the project was to identify and analyse individual and contextual factors influencing teachers' use of technology, and compare ways in which these factors come together to shape teachers' pedagogical identities. To do this, longitudinal case studies of four secondary school teachers who were selected to represent contrasting combinations of factors known to influence technology integration was undertaken. Valsiner's zone theory was used as the theoretical framework with the analysis of data conducted from a socio-cultural perspective. A comparison of similarities and differences between the teachers' professional identities was carried out to understand how these might influence the extent to which respondents adopt innovative practices involving technology. This provides a picture of each teacher's professional identity as an individual-acting-in-context.

While several studies provided data on the impact of laptops on motivation, attitudes and beliefs, computer skills, and leadership, less was done to track teaching and learning that occurs with laptops. While few available studies report improvement of learning outcomes in the majority of participating students, there are very few details on how reliable these results are and in what degree they can be attributed to the one to one access to computers. Many of these studies seem to measure the outcomes using special or standard tests or comparing marks from the report cards based on well defined knowledge and skills although there are indications that ICT, in general, and individual laptops, in particular can generate innovative learning and teaching approaches. Therefore, looking into the process of learning may provide us with more substantial insights.

According to recent research results, ICT can give a new dimension to teaching and learning, allowing students to solve more complex tasks and use powerful computer tools to get more information, represent it in many different ways, analyse it more efficiently, use dynamic tools, and finally produce new and often unexpected knowledge. Kennewell (2004) mentions a particular role ICT can play as a catalyst of intellectual challenges because it allows teachers to propose tasks to students within their zone of proximal development (in Vygotskian sense) and to give students feed-back. Klotz (2003) points at interactivity as a motivating factor for students, bringing them the pleasure of taking risks, to explore, to conjecture, and to test their hypotheses while learning from trial-and-error efforts, thus helping to develop such qualities as perseverance and the willingness to surpass themselves and to fully appreciate the fruits of their intellectual efforts.

\section{Methodology}

\section{Method and Design}

The study adopts a pure quantitative method using a survey approach. Survey approach was chosen in order to allow the researcher to draw on large sample which is representative of the total population (Babbie, 2004). Moreover, a survey approach is the most prominent approach used in previous related studies and because it is inexpensive especially when it is self administered. Survey is also useful when describing the characteristics of a larger population. The population for this study comprised the entire undergraduate students in the Faculty of Communication and Information Sciences, University of Ilorin, Nigeria. This group was chosen because; this is the only faculty where it is mandatory that students should own a laptop. Moreover, this group are information students learning about 21 st century technologies and how they work. Therefore, in terms of technologies at the University of Ilorin, the students in this faculty cannot be compared with any other faculties. This was why this study focused only this category of students. Hence, future 
research might look at a comparative analysis of laptops ownership between this faculty and others. In terms of sample selection, there are five departments that made-up the Faculty of Communication and information Sciences, at the University of Ilorin in Nigeria. Department of Computer Science, Library and Information Science and Mass Communication are already graduating students. So, they have students starting from Year 1 to Year 4. Unlike the other two Departments- Information Communication Science and Telecommunication Science that have students only in Year 1-3 as at the time this study was conducted. In the light of this, a total of 80 students (20 from each year of study) were selected from the Departments whose students spread from year 1-4; while 60 students (20 from each year of study) were selected from the two departments who have students only in years 1-3. This gives a total of 360 respondents (undergraduate students) that took part in the study. Data on the study was collected through a self designed questionnaire, the development of which was informed by the objectives of the study, research questions and literature review. To ensure the reliability of the questionnaire used in this study, a test re-tests reliability method of two weeks interval using Cronbach Alpha was adopted. The overall reliability was also determined through this effort. The correlation co-efficient of 0.75 and above suggests the questionnaire is highly reliable and can be recommended for future use (Marsh \& Hocevar, 1988). Before testing the reliability of the questionnaire used in this study, it was assumed that if the reliability co-efficient falls below 0.76 , this would still not stop its use in the study except that recommendations for the future use of the instrument would not be made. The 23 items questionnaire had overall reliability of 0.88 , exceeding the minimum standard of 0.80 suggested for basic research by (Wang and Tang, 2003). The questionnaire administration involved the researcher with the assistance from a group of 13 students who eventually did not take part in the study. Selected respondents in each department were administered the instrument during their departmental course. The administration exercise took five working days. One day for each department. A total of 360 copies of questionnaire were administered; however, 295 copies were returned completely filled. This gave an $82 \%$ return rate. This number was eventually used for data analysis in this study. Methods used for the analysis of the collected data involved percentages and frequency count. The results of the analyses are presented as follows:

Table 1: Demographic Information $N=295$

\begin{tabular}{|l|c|c|}
\hline Demographics & Frequency & Percentage \% \\
\hline Gender & & 58.6 \\
\hline Male & 173 & 41.4 \\
\hline Female & 122 & $\mathbf{1 0 0}$ \\
\hline Total & $\mathbf{2 9 5}$ & \\
\hline Departments & & 24.1 \\
\hline Computer Science & 71 & 25.4 \\
\hline Lib. and Information Sci. & 75 & 14.9 \\
\hline Mass Communication & 44 & 20.3 \\
\hline Information Comm. Sci. & 60 & 15.3 \\
\hline Telecommunication Sci. & 45 & $\mathbf{1 0 0 . 0}$ \\
\hline Total & $\mathbf{2 9 5}$ & \\
\hline
\end{tabular}




\begin{tabular}{|l|c|c|}
\hline Age & & 85.2 \\
\hline $\mathbf{1 6}-\mathbf{2 5}$ years & 253 & 14.5 \\
\hline $\mathbf{2 6}-\mathbf{3 5}$ years & 42 & 0 \\
\hline $\mathbf{3 6}-\mathbf{4 0}$ years & 0 & $\mathbf{1 0 0 . 0}$ \\
\hline $\mathbf{4 0}$ year + & $\mathbf{2 9 5}$ & \\
\hline Total & & 33.2 \\
\hline Year of Study (level) & 98 & 27.1 \\
\hline Year 1 & 80 & 25.4 \\
\hline Year 2 & 75 & 14.3 \\
\hline Year 3 & 42 & $\mathbf{1 0 0 . 0}$ \\
\hline Year 4 & $\mathbf{2 9 5}$ & \\
\hline Total & & \\
\hline
\end{tabular}

The demographic information of respondents who took part in the study in table 1 revealed that $173(58.6 \%)$ were male while $142(41.1 \%)$ were female. This indicates that more male than female took part in the study. Moreover, the demographic information on the respondents' department revealed that 75 respondents representing $(25.4 \%)$ were from the departments of Library and Information Science while 71 respondents (24.1\%) were from Computer Science department and 60 respondents $(20.3 \%)$ were from department of Information Communication Science. The department of Telecommunication Science had 45 respondents (15.3\%) and Mass Communication department had 44 respondents (14.9\%). The age distribution of the respondents revealed that 253 representing $(85.2 \%)$ fall within the age range of $16-25$ years, $42(14.5 \%)$ were in the age range of $26-35$ years while only no respondent's age fall within the age range of $36-40$ years and 41 years and above. In terms of the year/level of study, respondents in year $1(100$ level) constituted the majority 98 (33.2\%). This is followed by respondents in year two (200 level) with $80(27.1 \%)$ and next to this are the respondents in year 3 (300 level) $75(25.4 \%)$ while the least respondents $42(14.3 \%)$ were from year 4 (400 level). The final year respondents were rounding off their programme of study when the data for this study was collected. This might be the reason for their lower participation in this study.

Table 2: Laptop Ownership N =295

\begin{tabular}{|c|c|c|}
\hline Do you own a laptop? & Frequency & Percent \\
\hline Yes & 290 & 98.3 \\
No & 5 & 1.7 \\
Total & 295 & 100.0 \\
\hline
\end{tabular}

On the issue of laptop ownership, respondents were asked to indicate whether or not they own a laptop. A considerable number of the respondents indicated YES i.e.290 (98.3\%) while 5 respondents $(1.7 \%)$ indicated no. This is an indication that nearly all the students in faculty now own a laptop. 
Table 3: Reasons for Owning Laptop $N=295$

\begin{tabular}{|l|c|c|}
\hline Why do you own a laptop? & Frequency & Percent \\
\hline Because it is mandatory for CIS students & 145 & 49.2 \\
Because i can afford it & 25 & 8.5 \\
I want to be like others who owns it & 8 & 2.7 \\
I just feel like having it & 10 & 3.4 \\
I consider it useful & 99 & 33.6 \\
To show that I am information communi- & 8 & 2.7 \\
cation student & 295 & 100.0 \\
Total & & \\
\hline
\end{tabular}

On the reasons for owing laptop, table 3 reveals that $145(49.2 \%)$ indicated because it is mandatory as CIS students. A total of 99 respondents (33.6\%) indicated that they consider it very useful while 25 respondents $(8.5 \%)$ indicated they can afford it. A total of 8 respondents $(2.7 \%)$ each indicated that they own a laptop because they want to be like others and to show that they are Communication and Information Sciences students. These results clearly show that close to half of the respondents own a laptop because it is mandatory for them as CIS student.

Table 4: Difficulty of Having Laptop $\quad N=295$

\begin{tabular}{|c|c|c|}
\hline $\begin{array}{c}\text { Do you find it difficulty hav- } \\
\text { ing your own laptop? }\end{array}$ & Frequency & Percent \\
\hline Yes & 84 & 28.5 \\
No & 211 & 71.5 \\
Total & 295 & 100.0 \\
\hline
\end{tabular}

Table 4 above is to find out whether or the respondents find it difficult to own a laptop. A total of 84 respondents $(28.5 \%)$ indicated yes while on the contrary a considerable majority $211(71.5 \%)$ indicated they did not find it difficult having their laptop. The fact that students came from home with different social economic status (low, medium and high) may be responsible for this results.

Table 5: Extent of Difficulty in Owning Laptop $\quad \mathrm{N}=295$

\begin{tabular}{|l|c|c|}
\hline How difficult it is to have one? & Frequency & Percent \\
\hline Difficult & 61 & 20.7 \\
Not difficult & 188 & 63.7 \\
Very difficult & 41 & 13.9 \\
Extremely difficult & 5 & 1.7 \\
& & \\
Total & 295 & 100.0 \\
\hline
\end{tabular}


Table 5 find out the level of difficulty of owing a laptop. The results demonstrate that a total of 188 respondents representing $(63.7 \%)$ indicated it is not difficult while 61 respondents representing $(20.7 \%)$ contrarily indicated it is difficult. A total of 41 respondents $(13.9 \%)$ indicated it is very difficult while 5 respondents $(1.7 \%)$ indicated it extremely difficult. This means that it is not all that difficult for the students owing personal laptop.

Table 6: Acquisition of Laptop $\quad \mathrm{N}=\mathbf{2 9 5}$

\begin{tabular}{|l|c|c|}
\hline How do you acquire your laptop? & Frequency & Percent \\
\hline $\begin{array}{l}\text { My parent bought it for me } \\
\begin{array}{l}\text { Through a loan from coopera- } \\
\text { tive/bank }\end{array}\end{array}$ & 215 & 72.9 \\
$\begin{array}{l}\text { Through the money contributed } \\
\text { by friends }\end{array}$ & 6 & 7.5 \\
Through a gift from family friend & 12 & 2.0 \\
Through my pocket money & 40 & 4.1 \\
Total & 295 & 13.5 \\
\hline
\end{tabular}

Table 6 reveals information about the acquisition of laptop by the respondents. The results reveal that more than average respondents $215(72.9 \%)$ acquire their laptop through their parents who bought it for them. A total of 40 respondents $(13.5 \%)$ acquired their own laptop through personal savings while 22 respondents $(7.5 \%)$ acquired theirs through a loan from the bank and 12 respondents (4.1\%) acquired their own laptop through a gift from family friend. In addition, 5 respondents acquired their own laptop through money contributed by their friends for that purpose. Since the results reveal that some respondents find it easier to acquire laptop while others did not, table 7 find out how problem of difficulty in acquiring laptop can be solved. The result is presented in table 7 below.

Table 7: Ways of Overcoming Difficulty of Laptop Ownership $\quad \mathrm{N}=295$

\begin{tabular}{|l|c|c|}
\hline $\begin{array}{l}\text { How do you think the difficulty of having } \\
\text { personal laptop be overcome in this fac- } \\
\text { ulty? }\end{array}$ & Frequency & Percent \\
\hline Hire Purchase Installmental payment & 84 & 28.5 \\
Mandatory its acquisition & 17 & 5.8 \\
Making it inclusive in the school fees & 26 & 8.8 \\
Provision of Laptop Grant & 17 & 5.8 \\
Take up grants and subsidize the price & 72 & 24.4 \\
No response & 79 & 26.8 \\
Total & 295 & 100.0 \\
\hline
\end{tabular}


The results demonstrate that the problem of laptop acquisition can be solve through hire purchase and installmental payment indicated by 84 respondents $(28.5 \%)$. Another suggestion is by obtaining grants and subsidizes the price. This was indicated by 72 respondents (24.4\%). Another 26 respondents $(8.8 \%)$ suggest it should be included as part of their school fees. A total of 79 respondents $(26.8 \%)$ were neural they did not indicate whether yes or no.

Table 8: Importance of Having Laptop $\quad \mathrm{N}=295$

\begin{tabular}{|l|c|c|}
\hline $\begin{array}{l}\text { As a CIS student, do you think it } \\
\text { is important for you to have a lap- } \\
\text { top? }\end{array}$ & Frequency & Percent \\
\hline Yes & 274 & 92.8 \\
No & 21 & 7.1 \\
Total & 295 & 100.0 \\
\hline
\end{tabular}

On whether or not it is important for the CIS students to have a laptop, a total of 294 respondents $(02.8 \%)$ indicated yes while $21(7.1 \%)$ were of the contrary opinion indicating No. This implies that an over whelming majority support the fact that it is important to have a laptop as CIS student.

Table 9: Benefits of Laptop $\quad N=295$

\begin{tabular}{|l|c|c|}
\hline $\begin{array}{l}\text { What do you considered the } \\
\text { Benefits of having a laptop? }\end{array}$ & Frequency & Percent \\
\hline $\begin{array}{l}\text { For academic purpose such as } \\
\text { assignment and research }\end{array}$ & 127 & 45.1 \\
Make work easier and faster & 27 & 9.2 \\
Provide access to online discus- & & \\
sion & 51 & 17.3 \\
No response & 90 & 30.5 \\
Total & 295 & 100.0 \\
\hline
\end{tabular}

Table 9 reveals the benefits of having laptop. A total of 127 respondents representing (45.1\%) were of the opinion that laptop is beneficial for academic purpose such as assignments and research. Another 51 respondents $(17.3 \%)$ indicated that laptop provide access to online discussion forum while 27 respondents $(9.2 \%)$ indicated it makes work easier and faster. On the other hand, a total of 90 respondents $(30.5 \%)$ indicate no response. 
Table 10: Challenges of Using Laptop $N=295$

\begin{tabular}{|l|c|c|}
\hline $\begin{array}{l}\text { If yes what are the problem(s) you encountered } \\
\text { when using your laptop? }\end{array}$ & Frequency & Percent \\
\hline Lack of access to the internet connectivity & 197 & 66.7 \\
Intermittent of Power supply & 50 & 16.9 \\
Virus threat & 5 & 1.7 \\
Theft & 43 & 14.6 \\
Total & $\mathbf{2 9 5}$ & $\mathbf{1 0 0 . 0}$ \\
\hline
\end{tabular}

Table 10 reveals the challenges of owing and using laptop by CIS students. The results indicate lack of access to the internet connectivity in the faculty as the most prominent challenge with 197 respondents $(66.7 \%)$. This is followed by the challenge of intermittent power supply indicated by 50 respondents $(16.9 \%)$ and theft indicated by 43 respondents $(14.6 \%)$ while 5 respondents $(1.7 \%)$ indicated virus threat.

\section{Discussion of Findings}

The mandatory ownership and use of laptop reported in this study is not new as earlier stated in the background to this study. This is because extant literature has revealed similar case. For instance Newby (2000) reported a large, highly ranked public university implemented a requirement for all incoming undergraduates to own a laptop computer starting in fall, 2000. It is now widely accepted that effective use of technologies such as software, spreadsheets, graphics and CAS calculators, and data logging equipment offers students new opportunities for fast, accurate computation, collection and analysis of real or simulated data, and investigation of links between numerical, symbolic, and graphical representations of concepts.

Students own and use laptop because they want to be like others and to show that they are Communication and Information Sciences students. The benefits of laptop revealed by the study are use for academic purpose including assignments and research, provide access to online discussion forum and make academic work easier and faster. These results indicate, on the practical level, the positive effect of learning with personal laptops and routinely available ICT on students' achievements and competencies as revealed by Spector-Levy and Granot-Gilat (2012). The ownership and use of laptop is not new in the literature. Fullerton School District Laptop programme by Warschauer and Grimes (2005) and Maine's One-to-One laptop programme (Silvernail \& Lane, 2004) found that the use of this mobile technology during the teaching-learning process raises students' interests and that they are more actively involved in the learning process. Similarly, In terms of the use of resources, (Khambari et al. (2009) emphasised that laptop ownership gives users access to a greater range of resources primarily from the Internet. In addition, (Cunningham et al., 2004; Allen, Franceschini and Lowther (2010) ) also find similar results when they reported that personal access to laptops had allowed users greater freedom in accessing the Internet to search for resources. The study by Kichen (nd*) also lend a good credence to this present result by revealing that the students were more engaged during this unit of study than in previous units taught with more traditional approaches to teaching and learning. Despite no evidence of academic improvement, the students produced more high quality work with less help from the teacher. An improvement was also noted in the students' confidence in their data analysis skills between the start of the unit and its conclusion. 
The challenges of using laptop revealed by the study include lack of access to the internet connectivity in the faculty, intermittent power supply, and theft and virus threat. There is no perfect technology anywhere in the world. Irrespective of the expertise of the producer or the quality of the technology, there is bound to be one challenge or the other associated with whatever technology. Therefore, the challenges revealed associated with ownership and use of laptop in this study is not surprising. Even in the advanced nations of the world where availability of sophisticated technological infrastructure, yet they still face with one challenges or the other in terms of technology ownership and use.

\section{Conclusion}

The study has examined ownership and use of laptop among the information and communication sciences students at the University of Ilorin in Nigeria. The results have so far demonstrate that aside of being mandatory, students own and use laptop because they want to be like others and to show that they are Communication and Information Sciences students. It is not difficult owning personal laptop because it was bought or purchased by respondents' parents. To overcome problem of laptop acquisition, hire purchase and installmental payment, grants, price subsidy, and inclusion of payment for laptop in the respondents' school fees were identified. The benefits of laptop revealed by the study are use for academic purpose including assignments and research, provide access to online discussion forum and make academic work easier and faster; while the challenges of using laptop revealed by the study include lack of access to the internet connectivity in the faculty, intermittent power supply, and theft and virus threat.

\section{Recommendations}

It is clear from the results in this study that many respondents acquired laptop through the help of parents. However, there are some respondents whose parents cannot afford purchasing the laptop. In the light of this, it is recommended that the school/faculty authority should make opportunity available by subsidizing the price of laptop or alternatively the faculty can acquire this laptop in large quantity and allow the students to buy and make payment installmentally as indicated by Morris (2011) study as laptop use and support for students.

Since students use the laptop majorly for academic purposes including note taking, assignments, and research; the faculty/school should see to it that adequate access to the internet connectivity is provided without any restrictions. Moreover, it is important to improve the power supply on campus to facilitate better use of laptops by the students. In addition, adequate security should be provided to guide against the report of laptop theft.

One of the reasons behind the creation and establishment of the Faculty of Communication and Information Sciences is to promote communication and information and to produce graduate that will serve the growing demand for experts in the information industry. In the light of this, the major stakeholders in this faculty i.e. the ministry of information and communication in Nigeria should see to it that each student is given a laptop free of charge. This will assist in deepened the students' knowledge in their various courses and disciplines.

\section{Acknowledgment}

The author appreciates the effort by Library and Information Science 2012 final year student including Mr. Omotola, Kehinde and Olalekan Abdul-Azeez who analysed the data used in this study. The others (Mr. Tayo Martins, Ajibade, Demilade, Giwa Fuad, Dauda Ibrahim, Anonobi Jonathan, Adebayo Olaniyi, Jimoh Kazeem, and Opaleye Ifeoluwa) are all appreciated for their assistance in the administration of the instrument used for the collection of data in this study. The author also acknowledges the proof-reader of this manuscript in person of Profession L.O. Aina, 
the current Dean of the Faculty of Information and Communication Sciences, University of Ilorin, Nigeria. Thank you all.

\section{References}

Allen, L.E, Franceschini, L., \& Lowther, D. (2010). The role of school leadership in a large-scale student laptop implementation. Proceedings of Informing Science \& IT Education Conference (InSITE), 631645.

Babbie, E. (2004). The practice of social research (10th ed.). Belmont, CA: Thomson/Wadsworth.

Goos, M., \& Benison, A. (2008). Teacher professional identities and the integration of technology into secondary school mathematics. Paper Presented at the annual conference of the Australian Association for Research in Education Brisbane, 30 November - 4 December.

Gulec, J. C., \& Demitras, H. (2005). Learning with technology: The impact of laptop use on student achievement. The Journal of Technology, Learning, and Assessment, 3(2), 1-38.

Kennewell, S. (2004). Meeting the standards in using ICT for secondary teaching: A guide to the ITT NC. London: RoutledgeFalmer.

Khambari, M. N. M., Moses, P., \& Luan, W. S. (2009). Laptop ownership and use among educators: Reflections from school teachers in Malaysia. International Journal of Instruction, 2(2), 47- 72.

Kitchens, A. (n.d.). Using laptops to teach data analysis in seventh-grade mathematics. A Paper, Dodge County Middle School GA, United States

Klotz, G. (2003). Math: Calculating the benefits of cybersessions. In D. T. Gordon (Ed.), The digital classroom: How technology is changing the way we teach and learn (pp. 117-126). Cambridge: Harvard Education Letter.

Mang, C. F., \& Wardley, L. (2012). Effective adoption of tablets in post-secondary education: Recommendations based on a trial of iPads in university classes. Journal of Information Technology Education: Innovations in Practice, 11,302-317. Retrieved from http://www.jite.org/documents/Vol11/JITEv11IIPp301-317Mang1138.pdf

Marsh, H. W., \& Hocevar, D. (1988). A new, more powerful approach to multitrait-multimethod analyses: Application of second order confirmatory factor analysis. Journal of Applied Psychology, 73, 107-117.

Morris, P. G. (2011). Digital bridge or digital divide? A case study review of the implementation of the 'Computers for Pupils Programme' in a Birmingham secondary school. Journal of Information Technology Education: Innovations in Practice, 10, 17-41. Retrieved from http://www.jite.org/documents/Vol10/JITEv10IIPp017-031Morris899.pdf

Newby, G.B. (2000). Student laptop ownership requirement and centralization of information technology services at a large public university. Retrieved 12 September, 2012, from: http://www.petascale.org/papers/acit-laptop-final.pdf

Silvernail, D., \& Lane, D. (2004). The impact of Maine's one-to-one laptop program on middle school teachers and students. Portland, ME: Maine Educational Policy Research Institute.

Spektor-Levy, O., \& Granot-Gilat, Y. (2012). The impact of learning with laptops in 1:1 Classes on the development of learning skills and information literacy among middle school students. Interdisciplinary Journal of E-Learning and Learning Objects, 8, 83-96. Retrieved from http://www.ijello.org/Volume8/IJELLOv8p083-096Spektor0807.pdf

Warschauer, M. \& Grimes, D. (2005). First year evaluation report Fullerton School District Laptop Program. University of California, Irvine. 


\section{Biographies}

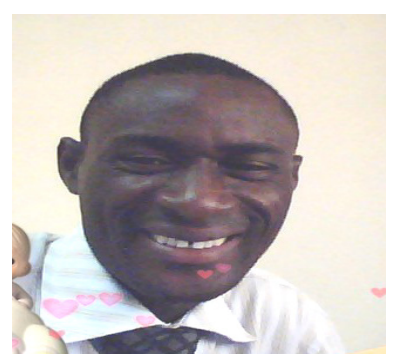

Adeyinka TELLA is a Senior Lecturer in the Department of Library and Information Science, Faculty of Communication and Information Sciences, University of Ilorin, Nigeria. Tella was a Commonwealth Scholar who finished his PhD in September 2009 from the Department of Library and Information Studies; University of Botswana where he was awarded small grant for thesis writing for the $\mathrm{PhD}$ student's category in 2007 by the Council for Development in Social Science Research in Africa (CODESRIA). He has written and published articles mostly in International reputable refereed journals together with chapters in books. He is one of the contributors to an information science reference "Cases on Successful E-learning Practices in the Developed and Developing World: Methods for the Global Information Economy" and Editor of another information science reference text 'Library and Information Science in Developing Countries: Contemporary Issues'. Currently, he is the Associate Editor International Journal of Library and Information Science, and Editor-in-Chief- International Journal of Information Processing and Communication. He is also editorial board member, for Library Philosophy and Practice and Malaysian Journal of Educational Technology. Tella is an external examiner for Library and Information Science PhD candidates at the Annamalai University, Alagapa University and Bharathidasan University, Trichy, in India. Tella has just been awarded a Post-Doctoral Research Scholarship by the University of Kwazulu-Nata in South Africa in April 2012. His re-search areas include e-learning, information literacy, information communication technology and management, information system evaluation and psychology of information.

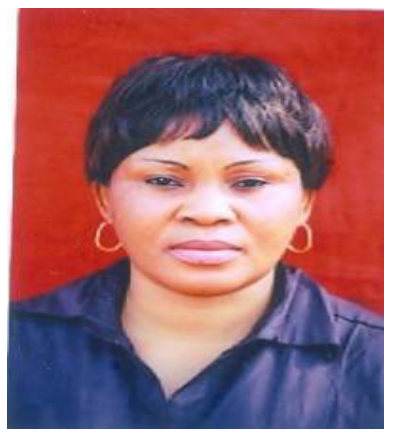

Ganiat Adebola KOSOKO-OYEDEKO is a lecturer in the School of Arts and Social Sciences, Michael Otedola College of Primary Education (MOCPED) Noforija Epe, Lagos State, Nigeria. She is also a graduating Ph.D. student at the University of Ibadan, Faculty of Education, Teacher Education Department, Ibadan, Oyo State, Nigeria. She has supervised many undergraduate students. 